\title{
The border as a resource - new places for tourism development. Evidence from two Carpathian tripoints
}

\author{
Marek Więckowski \\ Institute of Geography and Spatial Organization, Polish Academy of Sciences, Warsaw, Poland
}

\section{abstract}

Background: The development of cross-border tourism and local resources based on the border has grooving the importance in last decencies. One of the most important tourist attractions on Polish borders are tripoints. This article seeks to discuss changes made, by reference to two border tripoints situated on the junction of Polish, Czech and Slovak borders in the Beskids Mountains and on the junction of Polish, Slovak and Ukraine borders in the Bieszczady Mountains.

Material and methods: Analysis of historical, legal and statistical materials as well as cartographic analysis and fieldwork were conducted. Informal discussions and formal in-depth interviews were undertaken with tourists in each of the researched tripoints: informal interviews/discussions with 45 tourists in the tripoint between Poland, Slovakia and Czechia and informal interviews/discussions with 40 tourists in the tripoint between Poland, Slovakia and Ukraine.

Results: The tourists reaching tripoints in the Carpathians argued that the places have a great potential for tourism development. They underline great symbolic meanings, possibility to visit three countries in a short time and the importance of the point which is interesting and give an opportunity to take a nice photo. The presented research also exemplifies the concept of a new tourist space beyond traditional tourist destinations. This ensured the status of the tripoint as a resource, a "discovery", and a curiosity.

Conclusions: The border tripoints give great opportunities for the development of tourism. Openness and permeability of borders can determine development on both sides of tourism related to the presence of the border, and offer an opportunity for cross-border attractions to be set up. Tripoints as emerging tourist attractions have appeared in new marketing materials and have the potential to serve as unique border attractions.

Key words: tourism, Poland, Slovakia, Czechia, Ukraine, border, tripoint, European Union.

\section{article details}

Article statistics: Word count: 3,076; Tables: 0; Figures: 2; References: 25

Received: June 2021; Accepted: October 2021; Published: November 2021

Full-text PDF: http://www.balticsportscience.com

Copyright $\odot$ Gdansk University of Physical Education and Sport, Poland

Indexation: Celdes, Clarivate Analytics Emerging Sources Citation Index (ESCI), CNKI Scholar (China National Knowledge Infrastructure), CNPIEC, DOAJ, EBSCO - Central \& Eastern European Academic Source, EBSCO - SPORTDiscus, EBSCO Discovery Service, Google Scholar, Index Copernicus, J-Gate, Naviga (Softweco, Primo Central (ExLibris), ProQuest - Family Health, ProQuest - Health \& Medical Complete, ProQuest - Illustrata: Health Sciences, ProQuest Nursing \& Allied Health Source, Summon (Serials Solutions/ProQuest, TDOne (TDNet), Ulrich's Periodicals Directory/ ulrichsweb, WorldCat (OCLC)

Funding: This research received no specific grant from any funding agency in the public, commercial, or not-for-profit sectors.

Conflict of interests: Author has declared that no competing interest exists.

Corresponding author: Marek Więckowski, Institute of Geography and Spatial Organization, Polish Academy of Sciences; email: marekw@ twarda.pan.pl

Open Access License: This is an open access article distributed under the terms of the Creative Commons Attribution-Non-Commercial-NoDerivatives 4.0 International (https://creativecommons.org/licenses/by-nc-nd/4.0/), which permits use, distribution, and reproduction in any medium, provided the original work is properly cited, the use is non-commercial and is otherwise in compliance with the license. 


\section{INTRODUCTION}

Borderlines have long served as barriers to people's movements and their spatial development. Sometimes they have been closed and even subject to such a level of enforcement that any activity or movement into borderland zones was itself restricted or forbidden, with borderlands thus representing areas of isolation or no-man's land. Currently the development of tourism in borderlands is increasingly important. It has been facilitated by recent border openings and the changing role of borders since the widespread geopolitical and socioeconomic transitions of the past quarter-century in many parts of the world $[1,2]$.

The most attractive borders, ancient walls, and boundary curiosities have started to play more significant roles in tourism. It is thanks to attractions being associated with the boundary itself, a peripheral location, differences between sides, and the creation of crossborder space, that they tend to become tourist attractions [2]. Borders interest tourists as curiosities, symbolic elements, items of heritage and sources of education and learning $[2,3,4]$. In Europe, they also symbolise cooperation, while potentially attracting with unique marking, history and narration. One of the most interesting places on boundaries are tripoints. Tripoint could be defined as a place where three borders meet at one single point. This paper examines two tripoints situated in the Carpathians, both on the PolishSlovakian border, one where this border touches the Czech border and another where the border meets the border with Ukraine.

Due to the fact that knowledge about cross-border territorial cooperation is generally insufficient and this lack is evident both in theory and practice, especially in Poland and Central and Eastern Europe, the essence of this research is to deepen knowledge in this area, and in particular to identify the factors of creation of new trinational cross-border space. The conceptual underpinnings of the article relate to border and tourism relationships, transboundary identity, and the creation of multiscalar tourist space. Utilizing two case studies, the paper elucidates why tripoints matter for tourism from the tourist perspective. The research questions are defined as follows: why has the tripoint become tourist attraction and why is it interesting for tourists?

\section{BOUNDARY AS TOURIST ATTRACTION}

The constant change would seem to be a feature of most tourist destinations, not least as the creation and development of spaces for tourism are seen to reflect wider political, economic and social processes often driven non-locally, if manifesting themselves very locally indeed [5]. Radical changes are often an important element of transition in tourism [6, p. 1-2; 7], and these include political changes that have consequences for borderlands. The development of tourism at tripoints depends on various geopolitical issues, the level of benevolence or malevolence pertaining between the neighbours involved, the level of cross-frontier cooperation and the prospect of borders nearby being crossed. New tourist spaces are observable with changing border functions, and as tourism infrastructure is brought closer to state frontiers. This is particularly true in certain locations where the EU has expended considerable funds on tourism as a tool serving cross-border integration [8, $9,10,4]$. Many case studies relating to borderland tourism illustrate the important role of borders in the development of tourism in peripheral areas situated close to a border, in Poland, for example [11], but also in China [12] and in other countries [13, 4]. There is broad discussion of differences in tourism patterns and cross-boundary sites, including as regards the growth of cross-border cooperation and transboundary destinations [14, 15]. Cross-border cooperation is not easy $[16,8]$, but it offers the potential to tap into EU funds, allows for the creation of cross-border tourist space [2], and increases the symbolism of space within trilateral settings [17]. The European Union policy on transboundary integration and regions is being pursued via the Interreg programmes, whose aim has been to promote regional development and cross-border cooperation. The allocation of EU funds to these 
goals has represented a major instrument by which the Carpathian space can develop further. Equally, the cooperation involved is different from that on a two-country border, appearing more complex and expensive on the one hand, and most likely less effective on the other.

In most parts of the world, pillars, inscribed stones, or other symbols demarcate borders, to indicate the precise location at which two (or three) countries meet. These markers are legally-surveyed indicators of where one country's sovereign authority ends and that of another begins. Many tripoints have symbolic meaning attached to them as both special places located between three countries (with border markers, national flags, and monuments built in commemoration) and on a regional scale with the potential for transboundary cooperation [17, 18, 2]. Gelbman and Timothy note that, by boasting these kinds of attraction, borderlines highlight socio-economic differences, but can also shape socio-economic trends and patterns [19]. Differences visible on different sides of a border, even when three countries are in close proximity, add appeal to tripoints. And people are also attracted by the possibility of crossing borders and seeing the other side(s), especially where there are notable landscape differences, or different languages, currencies, religions or cultural customs [20].

\section{MATERIAL AND METHODS}

The attractiveness of tripoint by tourists was analyzed based on:

a) scientific literature concerning the aspects of nature-based tourism, tourism in border areas, tourism development in the Carpathians,

b) field work during many scientific travels to two tripoints in the Carpathians.

Informal discussions and formal in-depth interviews were conducted with tourists in each of the researched tripoints:

- between Poland, Slovakia and Czechia: informal interviews/discussions with 45 tourists - 15 from each country - in 2018 and 2019;

- between Poland, Slovakia, Ukraine: informal interviews/discussions with 40 tourists: 25 from Poland, 10 from Slovakia and 5 from Ukraine - in 2017 and 2018.

\section{THE SIGNIFICANCE OF THE CARPATHIAN BORDERLAND TO TOURISM}

The Carpathians possess specific resources important for different forms of development. Local and regional development is strongly dependent on the natural resource base of the area and this is an important factor for the existence of tourist attractions [21]. The Carpathians are one of the most important tourist regions in Poland and Slovakia. The PolishSlovak border features significant tourist attractions. It uses the potential of resources, symbolism and transboundary integration (via the place-based approach). This is particularly true of those working to develop regional projects who may mobilise tourism as a "placemaking instrument". As a consequence, we observe tourism's use of space in the creation of local or regional poles of growth and regional and cross-border competition as a development factor in tourist reception areas [11, 21, 22, 2]. During the long period, when the PolishCzechoslovak (currently Polish-Slovak and Polish-Czech) border constituted an impenetrable spatial barrier to tourism, it contributed to minimising the change in the natural environment by impeding the development of areas adjacent to the border, some of which were even explicitly sealed-off. When the border was opened [23, 21], these areas could boast both a quality environment and a variety of tourist attractions increased by those located across the border in the other country. 


\section{WHY HAVE THE TRIPOINTS IN THE CARPATHIANS BECOME ATTRACTIVE?}

The creation of tourist attractions related to tripoints begins with the delimitation and demarcation of borders. Next, such multi-nation spaces must be assigned a symbolic dimension, and a name, mainly for marketing purposes. Following this, several types of multi-scale development occur, in particular: tourism-facility development, improvement of access, organization of meetings and events, the creation of tourist attractions, and joint transfrontier marketing and planning [2]. In later years in both cases, tables and picnic areas were built, signs erected, and interpretive information panels put up. The tripoint has assumed further significance in its region, given that it has become a recognisable attraction. The regional authorities and hotel owners have noted this fact:

Even though expenditure at the tripoint itself is limited, tourists often stay on an extra day in this region's hotels, in order to travel to the three countries, as opposed to just one. More and more hotels pass on information about this special place, in the foyer leaflets they keep, but also on their own websites, under the "must-see" category. (Regional authority, Poland, 2019).

The vicinity of the tripoint offers a good foundation for cross-border cooperation, including the organisation of meetings, both for residents and tourists. At the beginning of recent transformations, the most important element was the possibility of crossing the border and the gradual improvement in accessibility and creation of new tourist routes. In 1993, after the formation of the tripoint, it was actually illegal to cross the border in its vicinity. The nearest border crossings were approximately 15-20 km away from it. In the case of Kremenaros tripoint, the biggest problem is the location of Ukraine outside the European Union and the Schengen zone, which causes the problems with border crossing.

The Polish-Slovak-Czech tripoint is located a significant distance from major cities and the capitals of each state, emphasising its peripheral location ( $2 \mathrm{~h} 40^{\prime}$ from Prague, $2 \mathrm{~h} \mathrm{40^{ \prime }}$ from Bratislava, and 4h 42' from Warsaw). The highest peripheral effect is shown in the Polish-Slovak-Ukrainian tripoint, which is situated very far from all capitals (6h $20^{\prime}$ from Bratislava, 6h 30' from Warsaw, and 9h 50' from Kiev). In the 1990s, it was essentially impossible to reach these points for legal and infrastructural reasons. In the 21st century, however, thanks to EU funds for peripheral regions, and transboundary cooperation, the infrastructure has dramatically improved, much reducing travel time to the tripoint from population centres [2]. Following significant improvement in accessibility, especially in the vicinity of the tripoint, people can now reach the site by car $\left(1 \mathrm{~h} 4^{\prime}\right.$ from Ostrava, $1 \mathrm{~h}$ from Žilina and 1h 36' from Katowice).

\section{THE TRIPOINT ON THE BORDER BETWEEN POLAND, SLOVAKIA AND CZECHIA}

The inclusion of the area into the European Union (2004) and the possibility of applying for EU funds thus became a major stimulus for tourism development. In 2004, the Tripoint Development Programme started as a grassroots initiative between the three neighbouring municipalities. It consists of local authorities, community groups and business associations from the three. Projects focusing on communication infrastructure have also been implemented as part of the Tripoint Development Programme. These include upgrading local roads mainly from surrounding villages to the border crossings. The Beskids tripoint area is known for its biking trails of various levels of difficulty. The easier tracks include one called 'The meeting point of three borders', which is $25 \mathrm{~km}$ long. Another one is $40 \mathrm{~km}$ long and much more difficult. Its name is 'Around the tripoint in the wake of Gary Fisher'. It was the century's end that brought a greater willingness to put a transboundary tourist product in place. 
The tripoint is also promoted on an international scale. For example, a workshop was coorganised in Brussels by the Regional Office of the Silesian Voivodeship, focusing on macro-regional cooperation. Polish, Czech and Slovakian cooperation in the tripoint area has been highlighted as a model of success. Tourists have similar opinions:

The place has its potential thanks to the out-of-the-ordinary location where the borders of Poland, Czechia and Slovakia meet. It can be thought of as a kind of special curiosity. It's a super feeling to move from country to country, and kids in particular have fun with that. (Czech tourist, 2018), [2].

Tourists themselves stressed that:

It's a fine place, but it's developing too slowly and new attractions are lacking. Let them do that new tri-bridge at last, as the old bridge is broken down and needs repairing. And there's still that small bar with Czech beer. (Polish tourist, 2018).

The regional zone does differ more markedly between the three states. On the Polish and Czech sides, the tourist infrastructure in the forms of hotels and bars is close to the tripoint. In turn, the Slovaks and Czechs resemble each other in putting more emphasis on the development of trails (serving active tourism by bike or on skis in particular). This reflects the greater mobility and level of activity in those societies, as opposed to Poland. Equally, the Polish and Czech sides are again similar in their higher level of accessibility (and greater numbers of potential tourists).

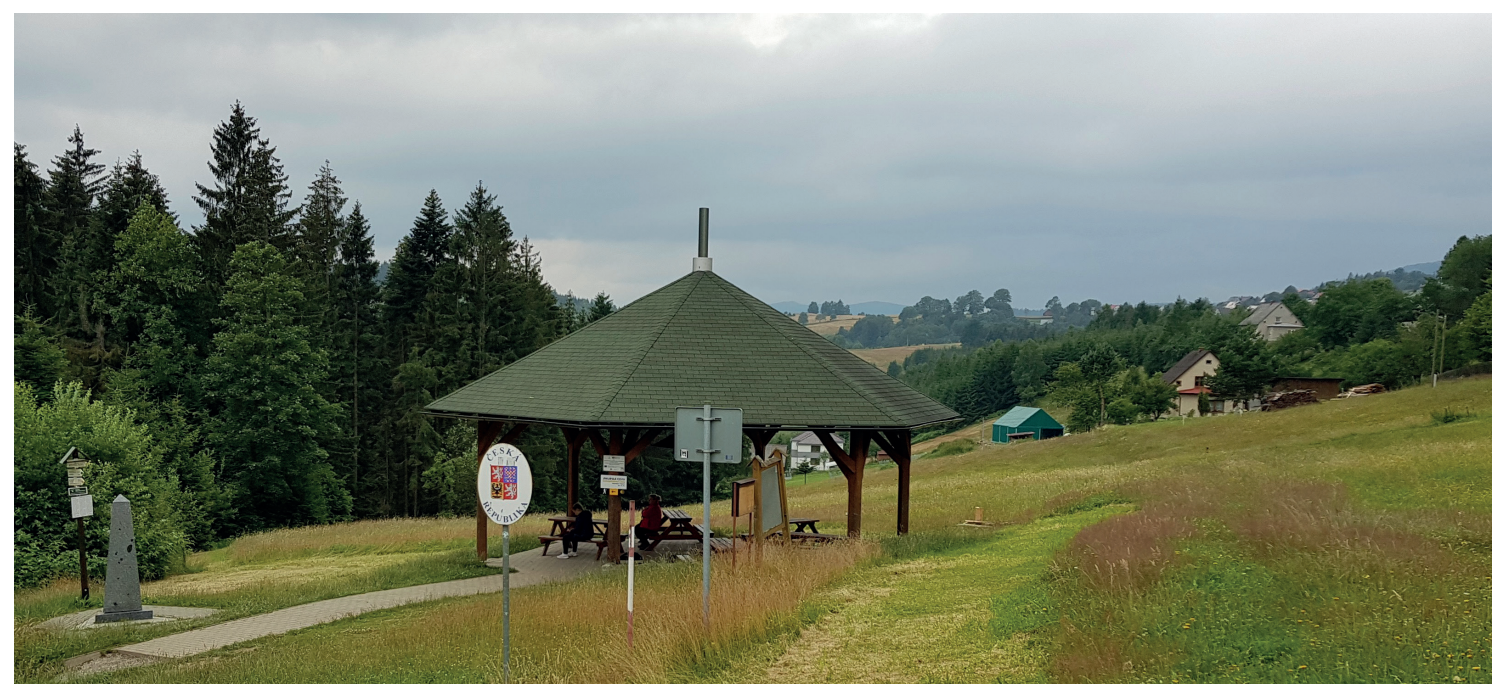

Fig. 1. The Beskids tripoint from the Czech side.

Source: Author

\section{THE TRIPOINT BETWEEN POLAND, SLOVAKIA AND UKRAINE}

The closed nature of the border with Ukraine (formerly with the Soviet Union) deepens the peripherality, as it makes access from the east difficult or impossible. This was used by the ecological domination and legal protection of very large areas of the Carpathians, access to which is difficult and limited. In a case of relatively closed borders as represented by external EU borders and former borders of the USRR, borderlands could be unpopulated and rich from natural point of view. Many nature protection areas could be established, but local cross-border cooperation is much more difficult in comparison with intergovernmental or international projects and issues. Furthermore, the formation of new transboundary patterns takes place. 
In recent years, there has been an increase in tourism-related infrastructure, tripoint markings and tourist information. The focal point is the obelisk erected in 2000 - with a mark on each side - the coat of arms, the name of the country and the name of the summit. Decorative border post in national colour and with coats of arms and name. Kremenaros has become a point of school trips and meetings of various social groups. Full trilateral cooperation is limited by the fact that Ukraine is not a member of the European Union and the fact that the border crossings that can be used to legally enter Ukraine are located far from the tripoint. However, there are attempts to organize joint, tripartite events in the region. For example, in 2010, workshops and the first edition of the Festival of Carpathian Flavours "Kremenaros" were organized, attended by specialists - experts in regional cuisine from Poland, Ukraine and Slovakia [23]. The tripoint has been highlighted as a model of success, and, additionally, new investments would complement the offer. Tourists have similar opinions:

A great place for a walk while being in three countries. In this place, an ideal lookout tower would be beautiful, the views above the treetops would be beautiful, maybe one day we will see it. (Polish tourist, 2018).

As many border places, the tripoint has a symbolic meaning, which is highlighted by a tourist from Slovakia:

It has a symbolic meaning, and it's great that you can visit such places without exposing yourself to the unpleasantness of border services. (Slovakian tourist, 2018).

Tourists emphasise the uniqueness of the tripoint and its particular attractiveness.

A unique place, after reaching it, however, a bit not prepared for rest and forces you to return quickly, the same way, the border posts make it easier. (Polish tourist, 2019).

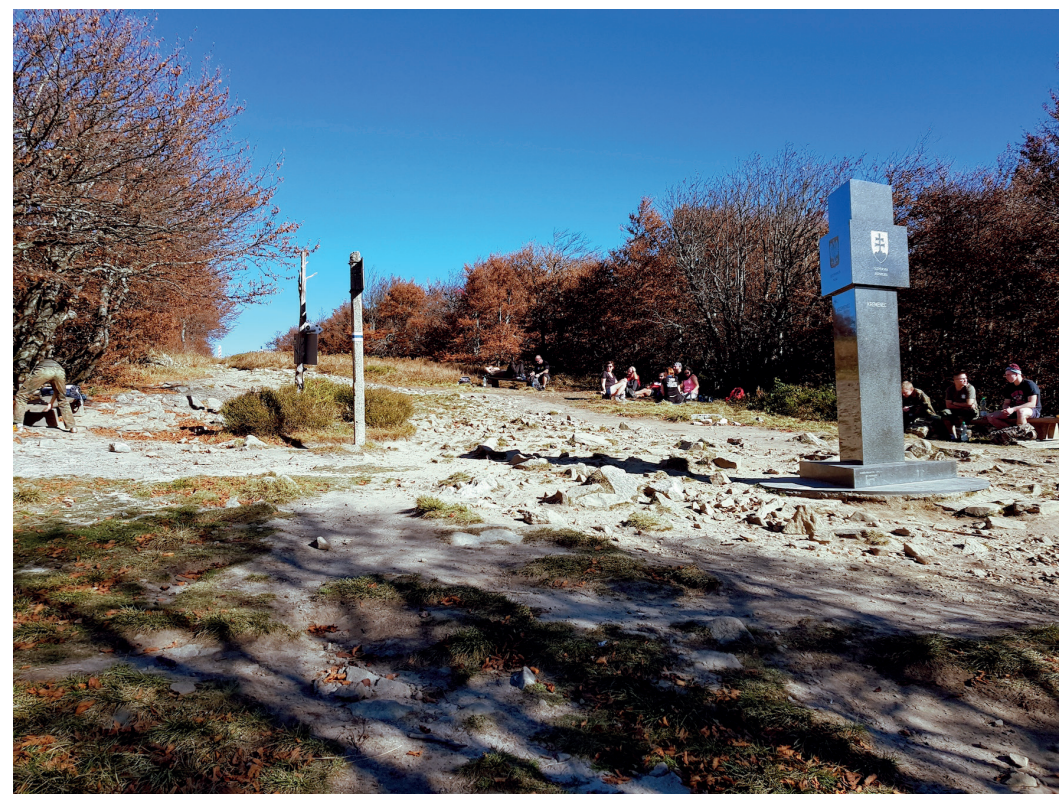

Fig. 2. The tripoint on the summit of Kremenaros

Source: Author

\section{DISCUSSION}

Borders mirror relations between neighbours - a changing combination of conflict, competition, subordination and cooperation, as well as the different aspects of the perception of a border [24]. The main components are similar to other tripoint locations in Europe, with the assumption of certain adaptations depending on the geopolitical situation and topography. 
Borders influence the development of tourism, including through motivation and associated decisions to travel, the development of tourist infrastructure, and the marketing and promotion of the region's brand [11]. Openness and permeability of borders can determine development on both sides of tourism related to the presence of the border and offer an opportunity for cross-border attractions to be set up.

Borders are an element separating different "worlds", and the very crossing of them is a change of environment so necessary for tourists and at the same time a great attraction [1]. "Just abroad" there is often an "otherness" that is very much sought after by tourists. Crossing borders offers tourists a sudden change, making the feeling of differences between two worlds seem particularly tangible. The fact that things can really be different even when a person has only travelled (or even looked) a few metres into the distance can be something mystical and fascinating [25, 1 p. 41, p. 43].

The border area is important for countries and as such it is frequently, if not always, also an area of symbolisation. The border is marked with boards and signs directly on the border line as well as the traffic corridors, hich cross the border. Gradually, a symbolic aspect can evolve for the elements of the cultural and historical heritage and natural monuments: all of them speak of 'our' country. These elements are generally also attractive and thus subject to visits. Symbolisation then gradually leads to the expansion of services in border areas and the case of two Carpathian tripoints is one of the examples of cross-border touristification of the place.

\section{CONCLUSION}

Through this article, an attempt has been made to better understand the role of tripoints in the establishment of transboundary tourist space in the Carpathians and the attractiveness of a tripoint for tourists. The author is quite aware that this article does not offer a full depiction of cross-border cooperation, given its necessary focus on just two small case studies selected that help exemplify them. The presented research also exemplifies the concept of a new tourist space beyond traditional tourist destinations [2]. Tripoints as emerging tourist attractions have appeared in new marketing materials and have the potential to serve as unique border attractions. The research detailed here is based on the author's conceptualisation of tourism development at tripoints and in their immediate vicinity, as an outcome of many years of fieldwork.

The aim being to facilitate understanding of the special role tripoints can play in tourism development has been analysed based on many informal interviews/discussions conducted by the Author with tourists. The tourists reaching both tripoints argued that the places have a great potential for tourism development. They underline great symbolic meanings, possibility to visit three countries in a very short time and the importance of the point which is interesting and gives an opportunity to take a nice photo.

In development of tourism in a tripoint, the most important element is the possibility to reach the borders of three countries in one place. This ensures the status of the tripoint as a resource, a "discovery", and a curiosity. The current period has seen the appearance of financial resources and projects funded by the European Union. The possibility of using EU funding has led to the construction of small-scale infrastructure, tourist-information installations and means of improved access (i.e. new roads into the area, parking lots and sidewalks). 


\section{REFERENCES}

[1] Timothy D. Tourism and political boundaries, Routledge Advances in Tourism. London and New York; 2001. https:// doi.org/10.4324/9780203214480

[2] Więckowski M., How border tripoints offer opportunities for transboundary tourism development. Tourism Geographies. 2021 (in press). https://doi.org/10.1080/14616688.2021.1878268

[3] Timothy, D.J., Saarinen, J. \&Viken, A., Tourism issues and international borders in the Nordic Region. Scand J Hospital Tourism. 2016;16(1):1-13. https://doi.org/10.1080/15022250.2016.1244504

[4] Wendt JA, Grama V, Ilieş G et al. Transport infrastructure and political factors as determinants of tourism development in the cross-border Region of Bihor and Maramureş. A comparative analysis. Sustainability. 2021;13(10):5385 https://doi.org/10.3390/su13105385

[5] Więckowski M, Saarinen J. Tourism transition, changes and the creation of new spaces and places in Central - Eastern Europe. Geographia Polonica. 2019;92(4):369-31717. https://doi.org/10.17163/GPol.0154a

[6] Müller D. Tourism and Transition. In D. Müller \& M. Więckowski (eds). Tourism in Transitions. Recovering Decline, Managing Change. Cham, Switzerland: Springer; 2018, 1-20. https://doi.org/10.1007/978-3-319-64325-0

[7] Mayer M, Zbaraszewski W, Pieńkowski D, Gach G, Gernert.Barrier effects of the Polish-Germanborder on tourism and recreation: The case of Protected Areas. An Introduction. In: Cross-border tourism in Protected Areas. Geographies of tourism and global change. Springer, Cham; 2019, 1-17. https://doi.org/10.1007/1978-3-030-051961-3

[8] Timothy DJ, Saarinen J. Cross-border cooperation and tourism in Europe. In: Costa C, PanyikE, Buhalis D, eds. Trends in European tourism planning and organisation. Bristol: Channel View Publications; 2013. https://doi org/10.21832/9781845414122-009

[9] Studzieniecki T, Meyer B. The programming of tourism development in Polish cross-border areas during the 2007 2013 period. 6th Central European Conference in Regional Science - CERS; 2017, 506-516.

[10] Dołzblasz S. A network approach to transborder cooperation studies as exemplified by Poland's eastern border. Geographia Polonica. 2018;191(1):63-76. https://doi.org/10.7163/GPol.00191

[11] Więckowski M. Tourism development in the borderlands of Poland. Geographia Polonica. 2010;83(2):67-81. https:// doi.org/10.7163/GPol.2010.2.5

[12] Zhang S, Zhong L, Ju H, Wang Y. Land border tourism resources in China: Spatial patterns and tourism management. Sustainability. 2019;11:236. https://doi.org/10.3390/su11010236

[13] Stepanova SV. The Northern Ladoga region as a prospective tourist destination in the Russian-Finnish borderland Historical, cultural, ecological and economic aspects. Geographia Polonica. 2019;192(4):4019-428. https://doi. org/10.7163/GPol.0156

[14] [Nilsson JH, Eskilsson L, Ek R. Creating cross-border destinations: Interreg programmes and regionalisation in the Baltic Sea area. Scand J Hospital Tourism. 2010;10:153-172. https://doi.org/10.1080/15022250903561978

[15] Prokkola EK, Lois M. Scalar politics of border heritage: an examination of the EU's northern and southern border areas. Scand J Hospital Tourism. 2016;16:sup1:14-35. https://doi.org/10.1080/15022250.2016.1244505

[16] Stoffelen A, Ioannides D, Vanneste D. Obstacles to achieving cross-border tourism governance: A multi-scalar approach focusing on the German-Czech borderlands. Ann Tourism Res. 2017;64:126-138. https://doi.org/10.1016/j. annals.2017.03.003

[17] Kałuski S. Trójstyki granic politycznych. Zróżnicowanie cech i funkcji [Tripoints of political borders. Differentiation in features and functions]. Czasopismo Geograficzne. 2016;87(2):101-115. Polish.

[18] Söhn C, Reitel B, Walther O. Cross-border metropolitan integration in Europe: The case of Luxembourg, Basel, and Geneva. Environ Plan. C Government and Policy. 2009;27(5):922-939. https://doi.org/10.1068/c0893r

[19] Gelbman A, Timothy DJ. From hostile boundaries to tourist attractions. Curr Iss Tourism. 2010;13(3):239-259. https:// doi.org/10.1080/13683500903033278

[20] Timothy DJ. Political boundaries and tourism: borders as tourist attractions. Tourism Manag. 1995;16(7):525-532 https://doi.org/10.1016/0261-5177(95)00070-5

[21] Więckowski, M. Natural heritage as a resource for tourism development in the Polish Carpathians. Geografickýčasopis. 2020;72(3):243-259. https://doi.org/10.31577/geogrcas.2020.72.3.12

[22] Faracik R. Granice polityczne a turystyka: wzajemne relacje na wybranych przykładach z Europy [Political borders and tourism: mutual relations based on selected examples from Europe]. In Sadowski P., ed. Rozwój turystyki kulturowej i przyrodniczej na pograniczu polsko-słowackim [Development of cultural and natural tourism on the Polish-Slovak border]. Nowy Targ (Podhalańska Państwowa Wyższa Szkoła Zawodowa); 2012, 11-17. Polish.

[23] Szpara K. Tourist border crossing points as elements of trans border cooperationin the Polish Carpathians. Prace Geograficzne. 2003;111:217-226.

[24] Kolosov V, Medvedev A, Zotova M. Comparing the development of border regions with the use of GIS (the case of Russia), Geographia Polonica, 2018;91(1):47-61. https://doi.org/10.7163/GPol.0090

[25] Ryden KC. Mapping the Invisible Landscape: Folklore, Writing and the Sense of Place. Iowa City: University of Iowa Press; 1993. https://doi.org/10.2307/j.ctt20h6sc9

\section{Cite this article as:}

Wieckowski M

The border as a resource - new places for tourism development. Evidence from two Carpathian tripoints

Balt J Health Phys Act. Balt J Health Phys Act. 2021;13(Spec. Iss.1):177-186

doi: 10.29359/BJHPA.13.Spec.Iss1.17 